PAPER • OPEN ACCESS

Student's computational thinking skill in solving a problem of convergences or divergences of series in freedom of learning program

To cite this article: M Dian 2020 J. Phys.: Conf. Ser. 1663012023
You may also like

- Power and responsibility in environmental
$\frac{\text { policy making }}{\text { Wenke Werner and M J Holler }}$
- Damped 2-DOF subsystems of acoustic
$\frac{\text { metamaterials }}{\text { P Szuchy and I Bíró }}$
- Concerns raised over climate submission
Michael Banks

View the article online for updates and enhancements.

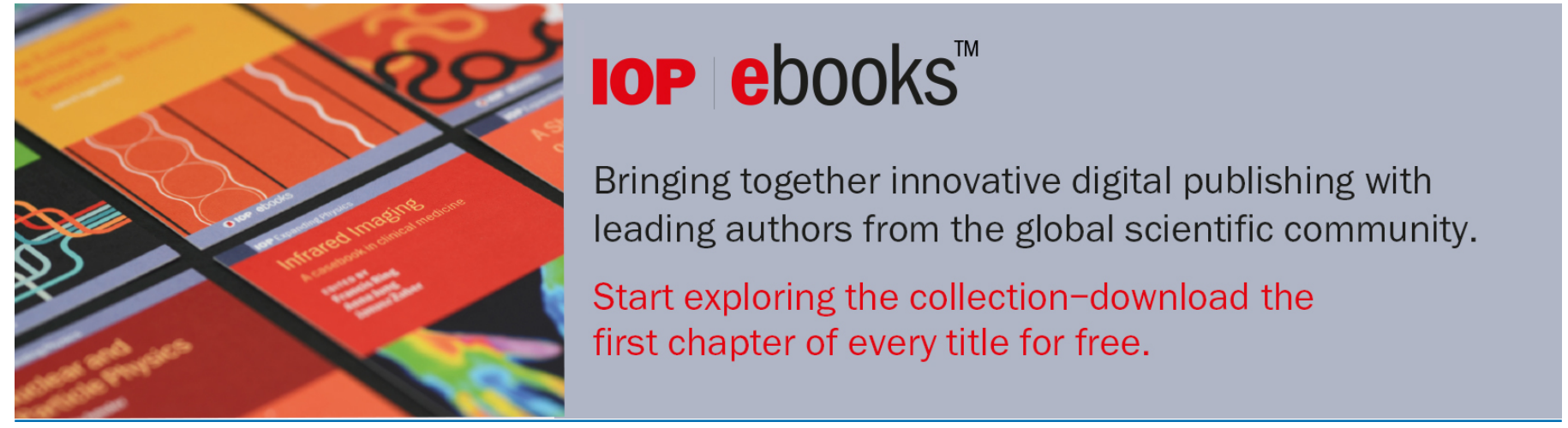

This content was downloaded from IP address 202.46.29.5 on 26/10/2021 at 03:29 


\title{
Student's computational thinking skill in solving a problem of convergences or divergences of series in freedom of learning program
}

\author{
M Dian \\ Department of Mathematics Education, Universitas Katolik Widya Mandala, Indonesia
}

Corresponding author's e-mail: mariani_dian@staff.widyamandala.ac.id

\begin{abstract}
This research aimed to find the connection between the trends in the Freedom of Learning Program and computational thinking (CT) practices to see if the Freedom of Learning Program could be used for developing students' CT Skill. The other goals of this research are to analyze how these trends and CT practices apply in a mathematics learning activity. The methods used in this research are the combination of the library and field research. This research also using a qualitative approach, and the results produced are descriptive data. Library research used to find the CT practices that could be applied in the nine trends in Freedom of Learning. Field research is used to analyze a student's mathematics learning activity to find CT practices and the trends that appear in the learning activity. The results of this research are (1) the CT practices could be applied in every trend with the students as the object of it, (2) in the learning activity every CT Practices (abstraction, decomposition, debugging, and patterns) appear, (3) Some trends of Freedom of Learning Program appear in the learning activity like the learning activity could be done anytime and anywhere, personalized learning, free choice, and project-based learning.
\end{abstract}

\section{Introduction}

We are entering the 4 th Industrial Revolution $\left(4^{\text {th }} I R\right)$, where we are facing an era where the technologies have a significant impact on our life. What kind of period is $4^{\text {th }}$ IR? As an explanation, here it's the illustration; The $1^{\text {st }} I R$, the primary mechanism of productions are water and steam. In the $2^{\text {nd }} I R$, electric power start to gain more quantity of production. Next, in the $3^{\text {rd }}$ IR, the electronics material and technology of information and communication are used to automate the production. Then, the $4^{\text {th }}$ IR is the enhancement of the $3^{\text {rd }}$ IR [1]. What kind of enhancement, then? $4^{\text {th }}$ IR is a stage of development in knowing where the lines between the physical and abstract spheres are being blurred [1][2]. We could see science and innovation advance in every field, for example, artificial intelligence (AI), Internet of Things (IoT), robotics, biotechnology, 3D printing technology, quantum computing, etc. [3]. $4^{\text {th }}$ IR then affect all of our aspect of life, and no exception for the educational world [4].

This era has its challenges as well as the opportunity for the education field, especially educational institutions. To be advanced, educational institutions must have the ability to innovate and able to collaborate. Educational institutions need to balancing the education system and the advancement of an era [5]. Risdianto says in $4^{\text {th }}$ IR, the education system is expected to have good critical thinking and problem solving, creative and innovative, and so communication and collaborative skills [5]. Lea also says that the necessary skills of workers needed for $4^{\text {th }}$ IR are complex problem-solving skills, critical 
thinking, innovation, human resource management, collaboration ability, emotional intelligence, judgment and decision making, service orientation, negotiation, and cognitive flexibility [6]. In this era, the educational system needs new skills besides reading, writing, and arithmetic. The skills including the skill to reading, analysis, and using the information in the digital world; technology literacy, such as understanding the machine's procedures and applying the technology; and lastly, human literacy, such as the strengthening of humanity, communication, and designing skills [5].

Education 4.0 then became a follow-up action to answer the $4^{\text {th }}$ IR needed for human resources. In education, 4.0, humans and technology are collaborating to find new possibilities [4]. Nine trends could be related to Education 4.0 which are learning can take place anytime and anywhere, personalized learning, students have the free choice in determining how they want to learn, project-based learning, hands-on learning, data interpretation, every student's assessment are different, considering the student's opinion in designing and updating the curriculum, and students become more independent in their learning [7]. In this sense, then Freedom of Learning Program is a form of Education 4.0. It can be seen in the learning activity of the Freedom of Learning Program, either it did inside or outside the campus environment, such as internship, project in the villages, teaching in schools, student exchange, research, entrepreneur activity, independent project, and humanity project [8].

In this era, Computational thinking (CT) also drawn quite good attention, along with the tendency to bring the fundamental and good quality of computer science (CS) to the education field [9][10]. CT is a problem-solving process that integrating the technology in it to find an effective and efficient solution to a problem using the concepts of computation [11]. CT has a close relation with CS [11][12], but in further development, the definition of CT is going through development. There are many opinions about what is $\mathrm{CT}$. One of them says that $\mathrm{CT}$ is the mental process for problems abstraction and the forming of the automatable solution [13]. Other states that CT is the thinking process to recognizing the computation aspects in our surroundings and how we were applying the tools and techniques from CS to understanding and reasoning about both natural and artificial systems and processes [14]. Based on the definitions, we could conclude that activities based on CT are essentially used to improve cognitive skills and also support the process of learning activity for the related individual [15].

Four essence practices could enhance CT skills, which are abstraction, decomposition, debugging, and patterns [16]. Two of them have many connections in mathematics and science problems, which is between decomposition and patterns [9]. Even if in the educational field, teachers or lectures not familiar with the term "debugging," but the point of finding and correcting mistakes emerge in these practices. Lastly, teachers or lectures may not be familiar with the term "abstraction" too, but abstraction has been acknowledged as a particularly crucial in CT practice [17][18][19].

Based on the theories above, this study will describe the connection between the trends of the Freedom of learning program and CT practices. Besides, describing the Freedom of learning programs can be used for developing students' CT skills. Then, to analyze how these trends and CT practices are applied in a mathematics learning activity.

\section{Methods}

The methodology used in this research is a combination of the library and field research. Library research is research using the literature review to find the results [15]. Library research with field research using the qualitative approach and produce descriptive data which is from the sentences or word that the subject has written or said [20][21]. A literature review was used to find what kind of CT practices that could be applied in the nine trends of education 4.0 or the Freedom of Learning program. The field research using students that attend the online class in calculus as a subject. There will be a review of what trends of education 4.0 and the CT practices used in this students learning.

\section{Result and discussion}

\subsection{Computational thinking practices in freedom of learning program}

The connection between the CT practices and the nine trends of Education 4.0 could be seen in table 1 . 
Table 1. CT practices in the trends of 4.0 education.

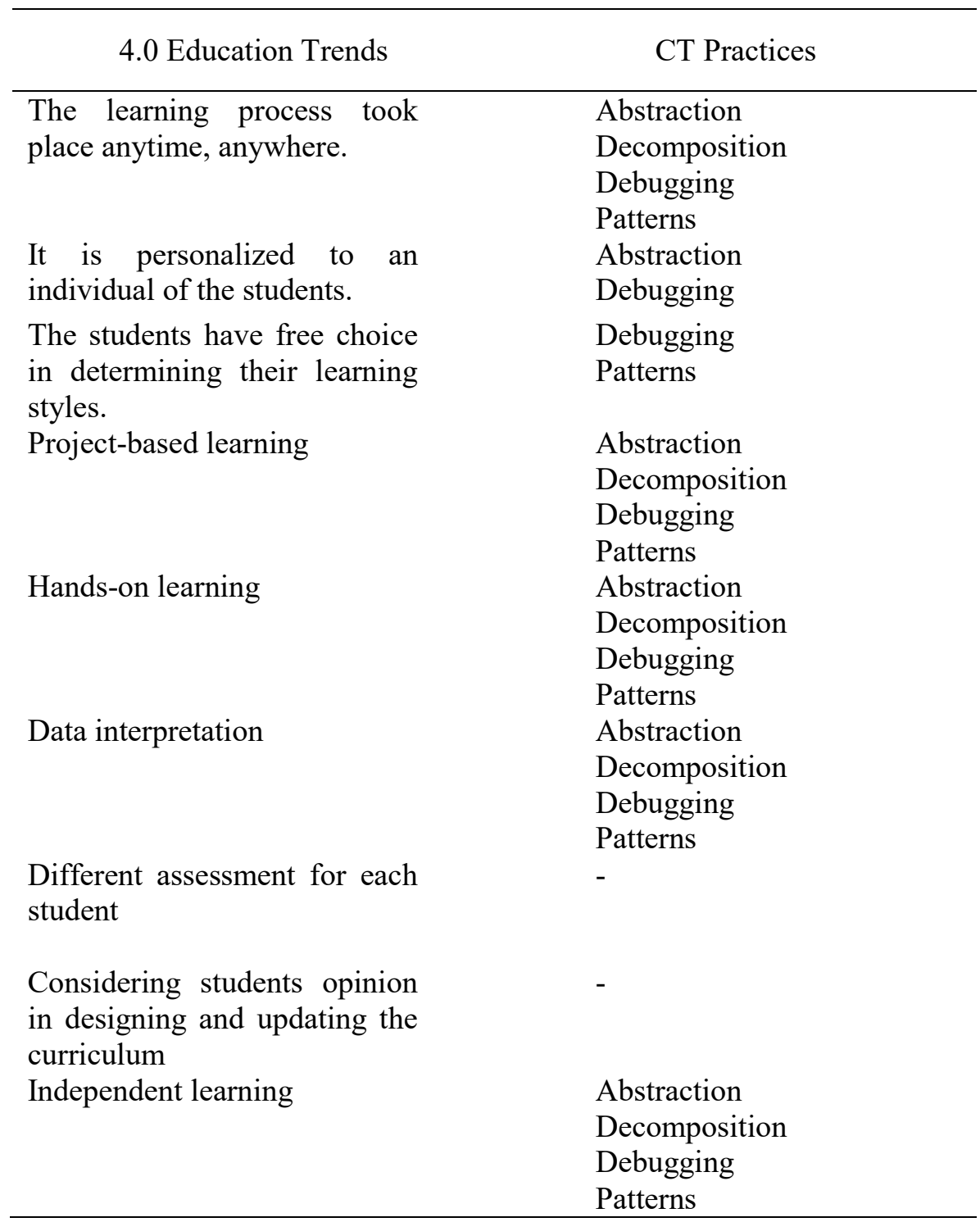

As we can see, the CT practices can be done in every trend of education 4.0 except for the different assessments for each student and considering students' opinions in designing and updating the curriculum because the object of these two trends is not the students. In the free choice of learning activity, the CT practices that could be done was a pattern, because to know what kind of learning activity that they like, students usually going through some good or bad experience in some activity. Students could ask what and why they got that learning experience, either it a bad or good one (debugging), and so after that, students could predict what kind of activity that suits them the best (patterns).

In personalized learning trends, the learning activity must be corresponding with the student understanding of the previous and the new information (Abstraction). To continue their learning activity to the next level, they must evaluate their knowledge of prior understanding (Debugging). The rest of the trends could be used to enhance the CT skills with the four main practices because these trends had direct access to the problem. For a complex problem, there will be used decomposition to parting the problem into other small problems that easier to find the solutions [11]. 
From this explanation, we know that for the 4.0 Education trends with the students as the object, the practices to developing the CT skill could be applied. Then, using the Freedom of Learning Program, which is one of the 4.0 Education embodiments, could develop the CT skill.

\subsection{Trends of education 4.0 and CT in student's learning activity}

In the learning process, the subject is given the task to find the solution to the question:

Find, for what value of $\mathrm{p}$ so that $\sum_{\mathrm{k}=1}^{\infty} \frac{1}{\mathrm{k}^{\mathrm{p}}}$ Convergence?

The result of this question is the series convergent for $p>1$. In this context, the student learning about the integral test to see the convergence of the series. Using this information and the previous result, the student asked to see what happen to the series if $p<1$. Because of the global pandemic, all of the learning activities doing by online media, so one of the media used in this activity, is WhatsApp.

Furthermore, Figure 1 is the response of the student, where the student sends his work and asking confirmation for the solution he got. He got the wrong answer because he just following the previous problem -solving process (for $p>1$ ). To build his understanding, the author then asked a question about the part of the main problem. The student was confused, so the author asks him to use the example, as shown in figure 1.

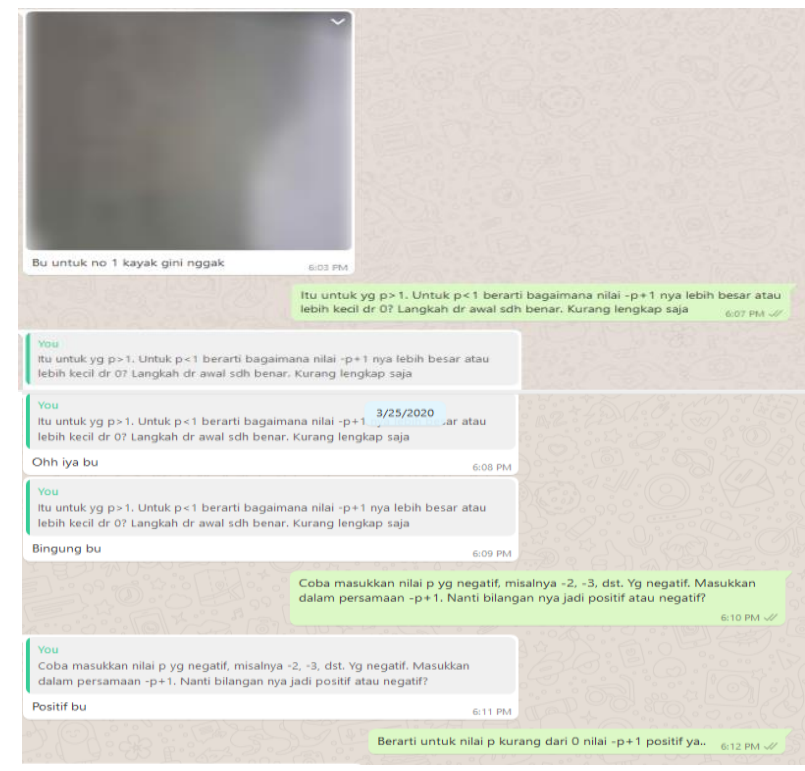

Figure 1. Learning activity-1.

In the first confirmation, it looks like the student still does not understand the problem. There is a question to make him understand, which is a small part of the big question. He was trying to make a conclusion using the example and giving the right answer after that. The process of decomposition appears when the author is asking the value of $-p+1$ for $p<1$. The process of abstraction also appears when students give a conclusion about the value of $-p+1$ from the example given, which is also using pattern recognition in it. The debugging process also appears when the author finds the wrong understanding of students' papers. In figure 2, the student starts to understand and trying to find the solution again, using the information he got. 


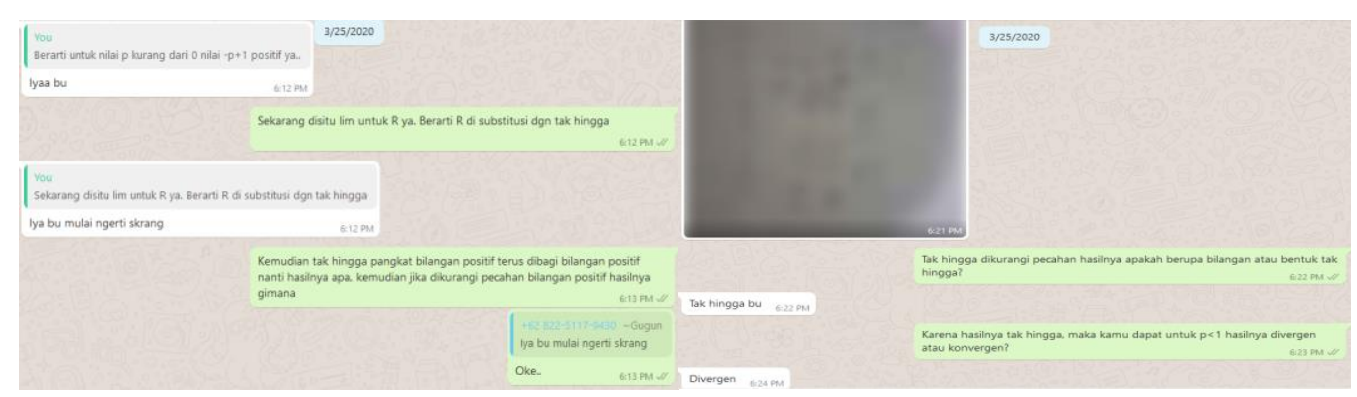

Figure 2. Learning activity-2.

Students are trying to do the abstraction process when he is trying to understanding the author's explanation. Again in figure 2, there is a debugging process when the student sent his work for the second time, but finally, he could find the pattern on the problem-solving process and give the right conclusion. The understanding process could be seen in figure 3 .

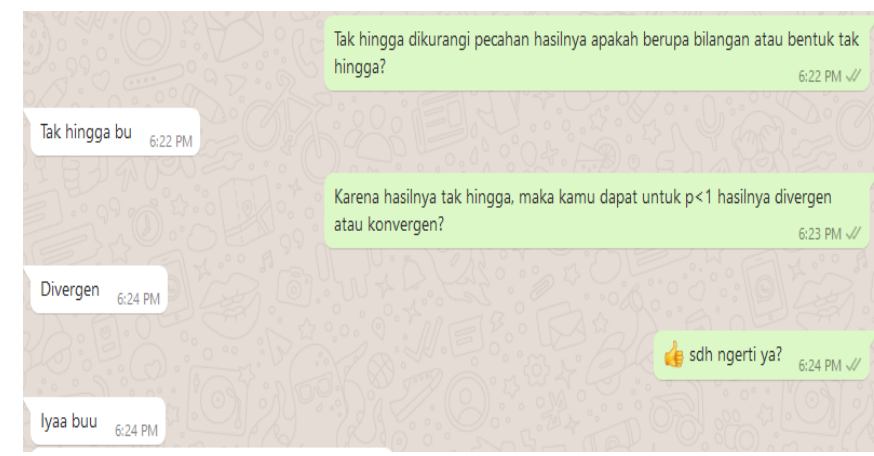

Figure 3. Learning activity-3.

Some trends of Freedom of learning also appear in this learning activity. First, using social media, the learning activity could be done anytime and anywhere [22]. Second, personalized learning appears in this activity; when students are not mastering some topics like the theory of numbering, integral calculus, limit, and some series theory, he could not find the solution. Third, using distance learning, students free to choose the learning activity they want. Fourth this learning activity could be a simple project learning.

\section{Conclusion}

Freedom of Learning Program is one of the terms of Education 4.0, and because of that, the nine trends in 4.0 Education also apply for the Freedom of Learning Program. Practices for developing students' computational thinking skills are applied in every trend with the students as an object in it. Freedom of Learning Program later could be used to developing students' CT skills. In the learning activity that's occurred, a student for observation on his problem-solving process, every primary practice appear in the process, which is an abstraction, decomposition, debugging, and patterns. Some trends of Freedom of Learning also appear in this learning activity, which is learning activity could be done anytime and anywhere, personalized learning, free choice, and project-based learning.

\section{References}

[1] Schwab K 2016 The Fourth Industrial Revolution: What It Means, How To Respond (Switzerland: World Economic Forum)

[2] Shahroom A A and Hussin N 2018 Int. J. Academic Res. Bus. Soc. Sci. 8 314-19

[3] Moeuf A, Pellerin R, Lamouri S, Giraldo T S and Barbaray R 2018 Int. J. Prod.Res. 56 1118-36

[4] Hussin A A 2018 Int. J. Educ. Literacy Stud. 6 92-8

[5] Yamin M and Syahrir 2020 Mandala Educ. 6 126-36 
[6] Lea Q T 2020 Int. J. Innov. Creativity Chang. 11 513-26

[7] Ramirez-Mendoza R A, Morales-Menendez R, Iqbal H and Parra-Saldivar R 2018 Global Engineering Education Conference (EDUCON) (Spain: IEEE Education Society)

[8] Direktorat Jendral Pendidikan Tinggi 2020 Buku Saku Panduan Merdeka Belajar Kampus Merdeka (Jakarta: Direktorat Jenderal Pendidikan Tinggi Kemendikbud RI)

[9] Rich K M, Yadav A and Schwarz C 2019 J. Technol. Teacher Educ. 27 165-205

[10] Tang X, Yin Y, Lin Q, Hadad R and Zhai X 2020 Comp. Educ. 148 1-22

[11] Wing J M 2006 Commun. ACM 49 33-35

[12] Wing J M 2011 Link Magazine 6 20-23

[13] Yadav A, Mayfield C, Zhou N, Hambrusch S and Korb J T 2014 ACM Transactions on Computing Edu. (TOCE) 14 5:1-5:16

[14] Furber S 2012 Shut Down or Restart? The Way Forward for Computing in UK Schools (Technical Report) (London: The Royal Society)

[15] Cansu S K and Cansu F K 2019 Int. J. Comp. Sci. Educ. Schools 3 1-11

[16] Rich K M, Yadav A and Larimore R A 2020 Educ. Info. Technol. 25 3161-88

[17] Armoni M 2013 J. Comp. Math. Sci. Teach. 32 265-84

[18] Hazzan O 2008 ACM SIGCSE Bulletin 40 40-43

[19] Kramer J 2007 Commun. ACM 50 37-42

[20] Moleong L J 2018 Metodologi Penelitian Kualitatif (Bandung: Remaja Rosda Karya)

[21] Zed M 2004 Metode Penelitian Kepustakaan (Jakarta: Yayasan Pustaka Obor Indonesia)

[22] Restian A 2020 J. Interdisciplinary Art Educ. 1 55-62. 